\title{
EDITORIAL
}

\section{The Generalist Approach}

\author{
Kurt C. Stange, $M D, P b D$, Editor
}

Ann Fam Med 2009;7:198-203. DOI: 10.1370/afm.1003.

$\mathrm{T}$ his article is the second in a series about ways to bring about integrated, personalized, highvalue health care. The first article ${ }^{1}$ outlined the problem of fragmentation. The next ${ }^{2}$ will elucidate the paradox of primary care. This article below illustrates the wisdom of a generalist approach that is deeply known but often overlooked in the fragmented world of modern healthcare.

\section{A TRUE STORY}

A cry through the door compels me to enter this examination room ahead of the next. having."

"Ahhhg. That's it! That's the pain I've been

Jim Bauer reaches toward his upper back, as his wife Doris looks on. Two weeks ago, I'd diagnosed Jim's muscle spasm, but it is no better after daily ibuprofen and 3 physical therapy appointments.

"There. Right there."

The bulge is unyielding under my fingers. Not firmly doughy like muscle should feel. This feels hard, almost like bone. It feels like a previously injured muscle now going into spasm. Most likely this rhomboid muscle was strained when Jim was gardening a few weeks earlier.

Reflexively, my hand switches from diagnosing to treating, letting the palm and heel do the pressing. I push gently at first, then with gradually rising pressure, the force distributed across the whole muscle. I imagine a musical crescendo.

"That really hurts!"

Neither the attempt at manual therapy nor my mental image works.

"Are the hot packs or ibuprofen or stretching exercises helping at all?"

"Nope. Nothing helps, except if I lean my back against the wall; sometimes that makes it go away."

Jim had lain off yard work and even stopped puttering around on his beloved boat, so I knew this pain was really irritating him.

"Go ahead and lean up against the wall if you want." The Bauers' faces relax as the pain decrescendos.
I shift my perspective and think anatomically. What's in this area of the body? A lot-muscles, bones, spine, nerves, heart, lungs, esophagus. A quick review of symptoms and further examination of these organ systems reveals nothing.

Fortunately, there are specialists for all the organs that could be the culprit. A physical therapist already is working on the muscle. An orthopedic surgeon could look for spinal or shoulder blade problems. (In Cleveland, we have different orthopedists for the spine and the shoulder.) A cardiologist would look at the heart and pericardium. A pulmonologist could say whether this was a lung problem, and send Jim back to me if it wasn't. A gastroenterologist would be delighted to pass a scope to look at the esophagus and stomach.

I am stymied and would love some help. But asking one of these specialists whether Jim has a disease in their area of interest, and getting the answer "not my table," if I choose wrongly, doesn't seem like a good option.

"Well, Jim, this still looks like a muscle spasm to me."

"It feels like one, too," grumps Jim, with the wry grin that has made him agreeable to me and endearing to Doris

"Right. But I'd have hoped it would be better by now. I think you should continue with the current treatment while we look a little further."

I give Doris instructions to call for Jim's CAT scan of the chest and back. Back pain and muscle spasm are common in family practice. But, I've known Jim for years, and something feels different here.

A week later, the radiologist pages me to say we got our money's worth from the CAT scan. I call Jim's house to ask whether I can bring over the pictures after supper. I take my time walking up the front path. Jim and Doris watch me through the screen door. They see the large manila folder containing Jim's CAT scan. There is no need for greeting or pleasantries.

Holding the x-ray image up to the light, I point to a round, white blob. An enlargement of the aorta occurs just after this artery turns southward after heading north from the heart toward the head. Jim's aorta measures $7 \mathrm{~cm}$ in diameter-already larger than the usual 6-cm threshold for operating to prevent rupture. 
As I tell them the news, Jim puts his hand on Doris' shoulder. Somehow he knows to ask whether there is anything else.

"Yes," I say. "There is a lump on the left kidney, about $3 \mathrm{~cm}$ in diameter. This was found by accident. In getting an image of the bottom of the lungs, sometimes the top of the kidneys comes into view, and the radiologist, noticed this."

"What is it?"

"Almost always lumps like this turn out to be a cancer of the kidney. I doubt this has anything to do with your pain. But that kidney probably needs to come out. You can live fine with just one kidney."

Shaking, Doris asks "What do we need to do?"

"There is something more," I venture. "A thickening of the esophagus. I think we need to look into that, too. It's in the right location to be causing the back pain."

"What is it?" Jim asks, looking at the poorly defined grey area.

"Possibly another cancer."

Now Jim sits down. Doris moves her chair close to Jim, holding his calloused hand in hers. "What do we need to do?" she asks again. This time, the shaking in her voice and hands is gone.

I review the situation. "First we need more information. We have found 2 things that could be causing the back pain. I still think the pain is from muscle spasms. But rather than being caused by overworking in the yard, the spasm may be caused by the aortic aneurysm or the esophageal thickening. We need to find out what the thickening is."

"Okay," say Jim and Doris together.

"I'1l arrange for you to see a gastroenterologist to take a look in your esophagus. I'd also like you to see a chest surgeon for advice about the aneurysm. I'll talk to both of them so that we all know what they find and recommend. I'll also call the physical therapist. I think you should keep up with the exercises and see if she has other ideas about treating the muscle spasm, knowing about these 2 possible causes."

"What about the kidney lump?" asks Doris.

"I think we can wait for now, but later I'll recommend a urologist. If you need an operation for one of the other things, perhaps the urologist could work on your kidney at the same time."

"Oh, and because of the aneurysm, we need to get your blood pressure even lower. In fact, lowering your blood pressure may make your back pain better. If it does, that would make me think that the aneurysm is the culprit."

During the next 3 years, I help orchestrate Jim's esophageal cancer diagnosis by the gastroenterologist, chemotherapy by the oncologist, and esophagus removal by the chest surgeon. Together, Jim, Doris, the chest surgeon, and I weigh the pros and cons of operating on the aneurysm and decide to hold off on an operation that could kill Jim or leave him paralyzed from disrupting the blood vessels that go from the aneurysm to the spinal cord. After his recovery from chemotherapy and chest surgery, I arrange for Jim to see a urologist, who removes his cancerous kidney. Sometimes, Jim has problems swallowing when the scar thickens where the surgeon hooked Jim's stomach up to the back of his throat after removing the esophagus. When this happens, I ask Jim to see the gastroenterologist for a dilation procedure. Not surprisingly, Jim has horrible acid reflux. When nothing else helps, I work with Jim's son, who lives in Canada, to get a new drug recommended by the gastroenterologist but not yet available in the United States. It helps. To minimize the risk of the aneurysm rupturing, I use multiple medications to lower Jim's blood pressure until he starts to feel dizzy, then back off, keeping the pressure as low as he can tolerate. Twice I hospitalize Jim for urgent blood pressure control when his back pain ominously returns, consulting the surgeon to confirm that an operation isn't needed.

I help Jim formulate his wishes in a living will, and care for the effect of his illness on Doris, integrating care of her anxiety and insomnia with management of her diabetes, hypertension, hypothyroidism, and arthritis. I try to make one medication work for her anxiety, insomnia, and arthritis pain, rather than using a different medication for each, and encourage lifestyle change rather than medication when possible. When Jim's blood pressure gradually increases, it serves as a malleable moment to encourage positive changes in Doris. They begin daily walks, which helps their high blood pressure and arthritis and reduces Doris' medication needs. It also gives Doris and Jim quiet moments to try to find meaning from Jim's illness and from a long life together that now seems more finite.

\section{THE GENERALIST APPROACH}

Jim and Doris needed a generalist who knew them well and who could help them manage their complex medical and emotional needs, ${ }^{3-9}$ interpreting and witnessing the interface between health and illness, ${ }_{1}^{10,11}$ guiding access to more narrowly focused care when needed. ${ }^{12}$ They needed the key aspects of primary care-firstcontact access, a comprehensive approach, coordination, and personalization of care. ${ }^{4,5}$ They also needed specialists who applied their technical skills and circumscribed expertise $\mathrm{e}^{13,14}$ within the context of generalist principles. They needed a health care system that values and is organized by these principles. ${ }^{15}$

The generalist approach ${ }^{16,17}$ encompasses funda- 
mentally important ways of being and knowing that often are devalued in our current ways of seeing and acting in complex situations. These situations include:

- Times of transition and instability

- Circumstances involving ambiguity and variability

- Situations where relationships and individualization matter

- Systems with a high degree of interconnectedness or complexity

- Settings in which both strongly and loosely related events unfold with time

- Situations where the whole is more than the sum of the parts

A narrowly focused approach is fine when an obvious problem is linked to a clear solution. When multiple problems ${ }^{18-23}$ are woven into the fabric of life, however, the generalist approach is critical.

A generalist approach involves working on the parts while paying attention to the whole ${ }^{24}$; being connected by sustaining relationships; having a broad base of knowledge while being grounded in specific information; scanning and prioritizing, then focusing on what is most meaningful; moving back and forth between the universal and the particular. ${ }^{25}$

The generalist approach is rooted in recognizing connection to person, community, and cosmos. It is not just a field or a discipline. It demands particular and widely applicable ways of being, knowing, perceiving, thinking, and doing. These ways are summarized in Table 1 and described below.

\section{Ways of Being}

The generalist ways of being involve an open stance, humility, and connection via key relationships. ${ }^{26}$ These traits must be developed before individuals and groups are ready to begin to know, perceive, and act with generalist wisdom. ${ }^{27}$ They must be supported by systems that connect individuals and foster communication.

When I burst into the room to see Jim's muscle spasm, I struggled to have an open stance. Remembering other times that I had mistakenly taken the easy explanation when all the pieces didn't quite fit helped to keep me humble. Humility helps openness. So does recognizing that we are only one part of a connected whole. To practice the generalist way, it is vital to be connected. This connection with others helps us see the whole and to deal with the uncertainty of recognizing that we cannot know everything. ${ }^{25}$

\section{Ways of Knowing}

Generalist ways of knowing are how society and individuals prepare to accomplish higher-order generalist functions. This training involves developing not only broad knowledge but also specific capabilities. It involves working to know oneself, others, the systems in which we operate, and the natural world, and how they are interconnected. ${ }^{28}$

College students engage in generalist training when they develop narrowly focused knowledge in a major topic and learn about the arts, sciences, and humanities. Conversely, when elementary schools make standardized tests more important than nurturing student's individual development and mastery, they are blocking the nascent generalist way of knowing from blossoming. ${ }^{29}$ Learners and practitioners need basic information in their field and broader knowledge to provide context for making sense. Knowledge becomes wisdom by searching for connections.

To be able to care for Jim, the specialists and I needed specific medical knowledge. The surgeon needed to weigh the risks of 2 chest diseases and have the technical skill to safely remove the cancerous esophagus. We needed data showing better outcomes if chemotherapy preceded, rather than followed surgery, so that we could involve the oncologist early in the process. As a generalist, I needed to know Jim as a person in the context of his family and community. I needed to know myself and my tendency to be superficial when distracted from my planned routine. I needed knowledge of the health care system and reflected-upon lived experience, as well as formal study in how these fields relate to each other.

\section{Ways of Perceiving}

Generalist ways of perceiving involve an integrated perspective, the core of the 
generalist approach. It involves scanning to take in the whole field, prioritizing what is most important, and then focusing energy on that highest priority. ${ }^{30-32}$

Generalist perceiving involves using all the senses to focus on the important particulars ${ }^{33}$ while keeping the whole in view. Information systems could support such perceiving, but most currently they only add to the cacophony of unprioritized prompts and noise. ${ }^{34}$

With Jim, I focused on the most likely cause of his pain. When an active retiree has back pain and you can see the muscle in spasm, it is usually a muscle strain. When it does not get better, when the spasm comes and goes, when it just seems unusual, it is important to have as broad a lens as possible. Jim's specialists were more effective by being involved when their particular knowledge and technical skills were most relevant. I was more effective as a generalist because of their expertise. A specifically talented particularist complements the role of the generalist. To be effective, both need to scan and prioritize. It is the breadth of the relationships, knowledge base, and field of vision that differ.

\section{Ways of Thinking and Doing}

Generalist ways of thinking and doing lead to prioritized, integrated action. This activity comes from engaging with the most important parts in context. It involves iterating (going back and forth) between breadth and depth, the subjective and the objective, action and reflection. ${ }^{25}$ Iteration is a key function in the generalist way.

Sometimes the generalist way involves doing multiple low-level tasks to enable higher level integrative action over time. ${ }^{2}$ For years before his back pain started, I monitored Jim's blood pressure, adjusted his medications, balancing good blood pressure numbers with how Jim felt every day when taking the medicines, and suggested more physical activity, all while picking up bits of the life story that provide the context of the person beyond the disease. Treating his arthritis involved making physical activity part of his and Doris' daily routine, adjusting medications, helping to decide when to consider joint replacement. With time, these little activities built mutual knowledge and trust, so that when we "got our money's worth" from a CAT scan, there was a deep bank account of relationship to draw on. This added value is largely invisible to the health care system, but it is a big part of why societies that base their health care systems on generalist principles have less waste and lower costs, greater equity, and better population health. ${ }^{35}$

The generalist ways of thinking and acting seeks connection. Increasingly, it is about teams, but to be effective, it must be about teams that foster personal connection rather than diffusion of relationship. It is about integrating parts - pieces of information and teams of people-into a meaningful whole. It is about putting a larger good and the other person before the wants of the self. Abiding with individuals and families and communities ${ }^{36}$ and perceiving the world as an integrated whole enable connection. A generalist approach enables love.

\section{A BIT MORE OF THE STORY}

Early one morning Doris awakes to find Jim shuddering, then unmoving and unconscious next to her in bed. She calls my house. I am away on a research trip to London.

My wife tells Doris to call 911. Even today, I wonder whether, had I been there, we would have been able to say that this is the end and avoid what followed. In my absence, Jim's chest is compressed and his lungs are ventilated. Because of his dire condition, the emergency medical technicians are required to take him to the nearest hospital, where the physician covering for me is not on staff and where Jim is not known.

After anticipating for years that such an event would be caused by the aneurysm rupturing, a CAT scan shows no leakage. The aneurysm is fine, but Jim is not. The intensive care specialist calls in a neurologist, who declares Jim brain dead. Surrounded by strangers, Doris and their children allow Jim's life support to be turned off, and he dies.

\section{WHAT WE CAN DO}

What if we took the long-known ${ }^{37-43}$ but oft-forgotten ${ }^{4-46}$ truths of generalist wisdom seriously? How would we redesign our systems? How would we change our reward structures? How would we revise our relationships, teams, and training? What would we build our technology to support? What kind of inner work would we do in ourselves? What can we do now?

We can refocus our health care system on improving the health of all citizens. ${ }^{47-50}$ Strong evidence ${ }^{4,5,35,51}$ shows that the way to improve health is to base the system on primary care-with first-contact access, a comprehensive approach, and personalization and coordination of care within the context of an ongoing generalist relationship, guiding access to more narrowly focused care when needed. ${ }^{4,5,12}$ In the United States, doing so will require rebuilding the workforce, reimbursement structure, and supportive systems for an expanded role for primary care teams. ${ }^{52}$ It will require generalists and primary care organizations recommitting to their generalist roots reimagined in the information age. It will require a rebirth of profes- 
sionalism not as an entitlement but as a larger responsibility to individuals and society. ${ }^{53,54}$ It will require rebuilding public health and creating new connections with a robust primary care infrastructure. It will require coordinating the efforts of specialists, generalists, public health workers, and the public on what each does best to promote health. ${ }^{22,55}$

We can focus more on fostering health than on enabling a healthcare industry. ${ }^{56}$ We can put greater resources into education, environment, sustainable economic development, primary care, and public health. ${ }^{57-}$ ${ }^{60}$ We can manage the politics of winners and losers by keeping the focus on the larger societal good that paradoxically benefits individuals as well. ${ }^{56}$

We can develop human and technological systems that support integration of care within ongoing relationships. We can develop information systems that foster integration and prioritization of care, ${ }^{34}$ rather than fragmenting disease management. ${ }^{61}$ Personalized medicine ${ }^{62-66}$ requires being in relationship with the person, ${ }^{67}$ not just knowing his genome.

We can recognize our commonality. We can know deeply that providing too much expensive, fragmented healthcare to some and too little basic care to others

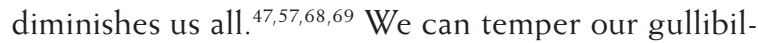
ity in believing that quick-fix, no-pain solutions exist for our complex problems. We can start with hope from where we are, knowing that workable systems look different in different locales as they evolve from different initial conditions. ${ }^{70,71}$ We can reward honest, straight talk and action among our leaders. We can cultivate the courage to take on the narrow selfinterest that fuels our system dysfunctions. We can be willing to sacrifice in the short term for a larger good in the long term. We can develop relationships with individuals and groups and societies that are different from us, and thus develop a broader sense of community.

As individuals, groups, systems, and society, we can strive to be humble, connected, and open. Seek broad knowledge grounded in specific experience. Perceive in ways that foster integration by scanning, prioritizing, and focusing on the most important particulars while keeping the whole in view. Think and act in ways that bring meaning to apparently low-level tasks that develop relationships, and iterate between the parts and the whole to foster a larger good.

This generalist approach is challenging and attainable. It is open to us all.

To read or post commentaries in response to this article, see it online at http://www.annfammed.org/cgi/content/full/7/3/198.

Funding support: Dr Stange is partially supported by a Clinical Research Professorship from the American Cancer Society.
Acknowledgments: For helpful comments on earlier drafts, I am grateful to Louise Acheson, Esa Davis, Frank deGruy, Willa Eisele, Ron Epstein, Kevin Fiscella, Ken Frisof, Robin Gotler, Sonja Haywood, Iona Heath, Ann Louise Kinmonth, Steven Landers, David Loxterkamp, Audrey Lynn, William Miller, Lynda Montgomery, Mary Ruhe, Mary Step, Paul Thomas, Cheryl Thompson, Carl Tyler, and James Werner.

\section{References}

1. Stange KC. The problem of fragmentation and the need for integrative solutions. Ann Fam Med. 2009;7(2):100-103.

2. Stange, KC, Ferrer RL. The paradox of primary care. Ann Fam Med, 2009, in press.

3. McWhinney IR, Freeman T. Textbook of Family Medicine. 3rd ed. New York, NY: Oxford University Press; 2009.

4. Donaldson MS, Yordy KD, Lohr KN, Vanselow NA, eds. Primary Care: America's Health in a New Era. Washington, DC: National Academy Press; 1996.

5. Starfield B. Primary Care: Balancing Health Needs, Services, and Technology. Revised ed. New York, NY: Oxford University Press; 1998.

6. Engel GL. The need for a new medical model: a challenge for biomedicine. Science. 1977;196(4286):129-136.

7. Saultz JW, Albedaiwi W. Interpersonal continuity of care and patient satisfaction: a critical review. Ann Fam Med. 2004;2(5):445-451.

8. Saultz JW, Lochner J. Interpersonal continuity of care and care outcomes: a critical review. Ann Fam Med. 2005;3(2):159-166.

9. Haggerty JL, Reid RJ, Freeman GK, Starfield BH, Adair CE, McKendry R. Continuity of care: a multidisciplinary review. BMJ. 2003;327(7425):1219-1221

10. Heath I. The Mystery of General Practice. London: Nuffield Provincial Hospitals Trust; 1995.

11. Launer J. Narrative-Based Primary Care. Abingdon, Oxon, UK: Radcliffe Medical Press, Ltd; 2002.

12. Stange KC, Jaén CR, Flocke SA, Miller WL, Crabtree BF, Zyzanski SJ. The value of a family physician. J Fam Pract. 1998;46(5):363-368.

13. Goldman L. The value of cardiology. N Engl J Med. 1996; 335(25):1918-1919.

14. Rosenblatt RA. Specialists or generalists. On whom should we base the American health care system? JAMA. 1992;267(12):1665-1666.

15. Grundy PH. Smart healthcare: Integrative solutions supporting a comprehensive healing relationship [eletter]. http://www. annfammed.org/cgi/eletters/7/2/100. 12 Mar 2009.

16. Gunn JM, Palmer VJ, Naccarella L, et al. The promise and pitfalls of generalism in achieving the Alma-Ata vision of health for all. Med J Aust. 2008;189(2):110-112.

17. Gunn J, Naccarella L, Palmer V, Kokanovic R, Pope C, Lathlean J. What is the place of generalism in the 2020 primary health care team? Australian Primary Health Care Research Institute. 2008. http://www.anu.edu.au/aphcri/Domain/Workforce/Gunn_3_ approved.pdf. Accessed Jan 12, 2009.

18. Fortin M, Bravo G, Hudon C, Vanasse A, Lapointe L. Prevalence of multimorbidity among adults seen in family practice. Ann Fam Med. 2005;3(3):223-228

19. Fortin M, Bravo G, Hudon C, et al. Relationship between multimorbidity and health-related quality of life of patients in primary care. Qual Life Res. 2006;15(1):83-91.

20. Fortin M, Dubois MF, Hudon C, Soubhi H, Almirall J. Multimorbidity and quality of life: a closer look. Health Qual Life Outcomes. 2007;5:52.

21. Fortin M, Soubhi H, Hudon C, Bayliss EA, van den Akker M. Multimorbidity's many challenges. BMJ. 2007;334(7602):1016-1017. 
22. Starfield B, Lemke KW, Herbert R, Pavlovich WD, Anderson G. Comorbidity and the use of primary care and specialist care in the elderly. Ann Fam Med. 2005;3(3):215-222.

23. Starfield B. Threads and yarns: weaving the tapestry of comorbidity. Ann Fam Med. 2006;4(2):101-103.

24. Stange KC. The paradox of the parts and the whole in understanding and improving general practice. Int J Qual Health Care. 2002;14(4):267-268.

25. Heath I. 'Uncertain clarity': contradiction, meaning, and hope. Br J Gen Pract. 1999;49(445):651-657.

26. Willis J. Friends in Low Places. Abingdon, Oxon, UK: Radcliffe Medical Press; 2001.

27. Platts MJ. The development of professional competence. In: Hagström A, ed. Engineering Education: Rediscovering the Centre. Zürich: vdf Hochschulverlag AG; 1999:153-158.

28. Stange KC, Miller WL, McWhinney I. Developing the knowledge base of family practice. Fam Med. 2001;33(4):286-297.

29. Willis J. The Paradox of Progress. Abingdon, Oxon, UK: Radcliff Medical Press, Ltd; 2002.

30. Epstein RM. Mindful practice. JAMA. 1999;282(9):833-839.

31. Epstein RM. Mindful practice in action (I): technical competence, evidence-based medicine and relationship-centered care. Fam Syst Health. 2003;21:1-10

32. Zoppi K, Epstein RM. Is communication a skill? Communication behaviors and being in relation. Fam Med. 2002;34(5):319-324.

33. McWhinney IR. 'An acquaintance with particulars...'. Fam Med. 1989;21(4):296-298.

34. Stead WW, Lin HS, eds. Computational Technology for Effective Health Care. Washington, DC: National Academies Press; 2009.

35. Starfield B, Shi LY, Macinko J. Contribution of primary care to health systems and health. Milbank Q. 2005;83(3):457-502.

36. Scott JG, Cohen D, Dicicco-Bloom B, Miller WL, Stange KC, Crabtree BF. Understanding healing relationships in primary care. Ann Fam Med. 2008;6(4):315-322.

37. Peabody FW. The care of the patient. JAMA. 1927;88:877-882.

38. McWhinney IR. The primary physician in a comprehensive health service. Further reflections after a visit to the United States. Lancet. 1967;1(7481):91-96.

39. McWhinney IR. Beyond diagnosis: an approach to the integration of behavioral science and clinical medicine. $N$ Engl J Med. 1972;287(8):384-387

40. McWhinney IR. Medical knowledge and the rise of technology. J Med Philos. 1978;3(4):293-304.

41. McWhinney IR. Primary care: core values. Core values in a changing world. BMJ. 1998;316(7147):1807-1809.

42. Stephens GG. The Intellectual Basis of Family Practice. Tucson, AZ: Winter Publishing Company; 1982.

43. Williams WC. The Doctor Stories / William Carlos Williams. compiled with an introduction by Robert Coles; afterword by William Eric Williams. New York, NY: New Directions; 1984.

44. Tolstoy L. The Death of Ivan Ilych. New York, NY: Penguin Red Classic edition; 1886 (2006).

45. Kaufman SR. The Healer's Tale. Madison, WI: The University of Wisconsin Press; 1993.

46. Muir E, Muir W, eds. Selected Short Stories of Franz Kafka. New York NY: Modern Library; 1952.

47. Woolf SH. Society's choice: the tradeoff between efficacy and equity and the lives at stake. Am J Prev Med. 2004;27(1):49-56.
48. Woolf SH, Johnson RE, Fryer GE Jr, Rust G, Satcher D. The health impact of resolving racial disparities: an analysis of US mortality data. Am J Public Health. 2004;94(12):2078-2081.

49. Woolf SH, Johnson RE. Inattention to the fidelity of health care delivery is costing lives. Am J Pub Health. 2007;97:1732-1733; author reply 1733.

50. Woolf SH. A closer look at the economic argument for disease prevention. JAMA. 2009;301(5):536-538.

51. Baicker K, Chandra A. Medicare spending, the physician workforce, and beneficiaries' quality of care. Health Aff (Millwood). 2004;(Supp Web Exclusives):W184-197.

52. Bodenheimer T, Grumbach K. Improving Primary Care: Strategies and Tools for a Better Practice. New York, NY: Lange Medical Books/ McGraw-Hill; 2007

53. Platts MJ. Participating in the work of creation. ESTIEM Summer Academy 2003. http://www3.estiem.org/sac/sac2003/docs/pitwoc. pdf. Accessed Mar 20, 2009

54. Platts MJ. Developing competence and trust: maintaining the heart of a profession. Prof Ethics. 2003;11(1):3-18.

55. Stange KC. Shared care: what mix of generalist and specialist care optimizes patient outcomes? J Fam Pract. 1999;48(3):177-179.

56. Allard J, Davidson C, Matthaei J, eds. Solidarity Economics: Building Alternatives for People and Planet. Chicago, IL: ChangeMaker Publications; 2008.

57. Woolf SH, Stange KC. A sense of priorities for the healthcare commons. Am J Prev Med. 2006;31(1):99-102.

58. World Health Organization. Commission on Social Determinants of Health-Final Report. 2008. http://www.who.int/social_determinants/ final_report/en/index.html. Accessed Jan 30, 2009.

59. Institute of Medicine Committee on Health and Behavior. Health and Behavior: The Interplay of Biological, Behavioral and Societal Influences. Washington, DC: National Academy Press; 2001.

60. Etz RS, Cohen DJ, Woolf SH, et al. Bridging primary care practices and communities to promote healthy behaviors. Am J Prev Med. 2008;35(5)(Suppl):S390-S397.

61. Geyman JP. Disease management: panacea, another false hope, or something in between? Ann Fam Med. 2007;5(3):257-260.

62. Aspinall MG, Hamermesh RG. Realizing the promise of personalized medicine. Harv Bus Rev. 2007;85(10):108-117, 165

63. Carlson RJ. The disruptive nature of personalized medicine technologies: implications for the health care system. Public Health Genomics. 2009;12(3):180-184.

64. Collins F. Francis Collins interview. Departing U.S. genome institute director takes stock of personalized medicine. Interview by Jocelyn Kaiser. Science. 2008;320(5881):1272

65. Lesko LJ. Personalized medicine: elusive dream or imminent reality? Clin Pharmacol Ther. 2007;81(6):807-816.

66. Svinte M. The promise of personalized medicine: a conversation with Michael Svinte. Interview by Michael Millenson. Health Aff (Millwood). 2006;25(2):w54-w60.

67. Buber M. I and Thou. 2nd ed. New York, NY: Scribner; 1958.

68. Franks P, Clancy CM, Nutting PA. Gatekeeping revisited-protecting patients from overtreatment. N Engl J Med. 1992;327(6):424-429.

69. Woolf $\mathrm{SH}$, Johnson RE. The break-even point: when medical advances are less important than improving the fidelity with which they are delivered. Ann Fam Med. 2005;3(6):545-552.

70. Gawande A. Annals of public policy: getting there from here: how should Obama reform health care? The New Yorker; 2009.

71. Meads G. Primary Care in the Twenty-First Century. Seattle, WA: Radcliffe; 2006. 